\title{
Cijfers en beelden
}

Citation for published version (APA):

Backes, W. H. (2014). Cijfers en beelden. Maastricht University. https://doi.org/10.26481/spe.20140711wb

Document status and date:

Published: 07/11/2014

DOI:

10.26481/spe.20140711wb

Document Version:

Publisher's PDF, also known as Version of record

\section{Please check the document version of this publication:}

- A submitted manuscript is the version of the article upon submission and before peer-review. There can be important differences between the submitted version and the official published version of record.

People interested in the research are advised to contact the author for the final version of the publication, or visit the DOI to the publisher's website.

- The final author version and the galley proof are versions of the publication after peer review.

- The final published version features the final layout of the paper including the volume, issue and page numbers.

Link to publication

\footnotetext{
General rights rights.

- You may freely distribute the URL identifying the publication in the public portal. please follow below link for the End User Agreement:

www.umlib.nl/taverne-license

Take down policy

If you believe that this document breaches copyright please contact us at:

repository@maastrichtuniversity.nl

providing details and we will investigate your claim.
}

Copyright and moral rights for the publications made accessible in the public portal are retained by the authors and/or other copyright owners and it is a condition of accessing publications that users recognise and abide by the legal requirements associated with these

- Users may download and print one copy of any publication from the public portal for the purpose of private study or research.

- You may not further distribute the material or use it for any profit-making activity or commercial gain

If the publication is distributed under the terms of Article $25 \mathrm{fa}$ of the Dutch Copyright Act, indicated by the "Taverne" license above, 
Prof. dr. ir. Walter H. Backes

FHML

Cijfers en Beelden 


\section{Cijfers en Beelden}

Inaugurele rede Walter Backes

Uitgesproken bij de aanvaarding van het ambt van

bijzonder hoogleraar in de Klinische Fysica, i.h.b. Neuroimaging, aan de Universiteit Maastricht

Maastricht, 7 november 2014

Door prof.dr.ir. W.H. Backes

\section{Overzicht}

Mijnheer de dekaan, leden van de Raad van Bestuur, leden van het College van Toezicht, vakgenoten, collega's, vrienden en familie. Ook ik heet u en jullie van harte welkom bij de inaugurele rede voor het aanvaarden van de leerstoel hier aan de Universiteit Maastricht. De leerstoel heet Klinische Fysica, in het bijzonder de Neuroimaging. Ik ga u hier uitleggen wat we hiermee willen, wat we reeds doen en waar we onze speren op hebben gericht.

Ik begin ermee $u$ te vertellen wat een klinisch fysicus is, wat hij/zij doet, hoe die wordt opgeleid en wat er landelijk hieromheen speelt. Vervolgens ga ik in op het wetenschappelijk beeldvormende onderzoek, en met name onze rol ten aanzien van de 'cijfers en beelden'. En vreest het niet, ik zal spaarzaam zijn met de taal die een fysicus doorgaans spreekt, die van vergelijkingen en formules, want zo'n rede dient immers voornamelijk het gesproken woord te bevatten.

\section{Wat is een klinisch fysicus?}

Allereerst het vakgebied. De Klinische Fysica valt niet meer weg te denken uit onze heden ten daagse zorgcentra. Zelfs de meeste kleinere ziekenhuizen hebben er in recente jaren een of meerdere in dienst genomen. Desondanks blijft het voor sommige specialisten een ongedefinieerde professie. Dat komt enerzijds omdat we relatief klein in aantal zijn, maar waarschijnlijk ook door de verscheidenheid aan onderwerpen waarin klinisch fysici werkzaam zijn en zich hebben gespecialiseerd. Breed gesteld is de Klinische Fysica het vakgebied waarin fysische, dus natuurkundige, methodieken in de gezondheidszorg worden toegepast. Klinisch Fysici zijn in Nederland voornamelijk werkzaam in academische en algemene ziekenhuizen, en in audiologische of radiotherapeutische centra die soms zelfstandig 
zijn. Hoe komt dat? Aan het grootschalig maken van o.a. röntgenfoto's en het werken met radioactieve stoffen, dus het werken met ioniserende straling, kleeft een mogelijk gezondheidsrisico. Dat is de oorspronkelijke reden dat zorginstellingen volgens de kernenergiewet verplicht zijn een klinisch fysicus beschikbaar te hebben. Naast het reilen en zeilen met stralingsbescherming zijn zij vaak belast met taken analoog hieraan zijn, zoals veiligheidsmanagement en risicoanalyses. Daarnaast spelen zij vaak een rol bij de aanschaf van medische apparatuur, met name die die veelal duur en complex is. De nauwe verwevenheid met de gezondheidszorg heeft er toe geleidt dat in 2009 het beroep Klinisch Fysicus officieel is opgenomen in artikel 34 van de wet BIG - de wet over de Beroepen in de Individuele Gezondheidszorg. $\mathrm{Nu}$ het gaat hier om veel, teveel activiteiten over vele specialisaties van zorg die in voortdurende ontwikkeling zijn. Dat is niet door één persoon te bewerken of helemaal bij te houden. Dit sluit ook aan bij hetgeen emeritus professor Van Engelshoven, voormalig afdelingshoofd Radiologie, schetste in zijn afscheidsrede, toe hij zei dat de technologie aan het einde van iemands carrière in niets meer hetzelfde is in vergelijking met die toen hij startte.

\section{Voorbeeld rol Klinische Fysica - Nieuwbouw Verheylaan-10}

Een voorbeeld waaraan de klinisch fysici van de eenheid Beeldvorming werken ziet u hier. $U$ ziet hier een schets, layout, van de nieuwbouw zoals dat nu gebouwd wordt naast het bestaande gebouw van het Academisch Ziekenhuis Maastricht, de Verheylaan-10. Deze wordt in de eerste helft van 2016 opgeleverd, zo is de verwachting. Het gaat hier om de laagste etage, die van de begane grond, waar enerzijds een MRI centrum wordt ingericht, voor de zware onderzoeksmachines die nu op maar liefst 4 verschillende locaties van het azM zijn gehuisvest. Op dit moment is het een heuse IQ test voor iedere patiënt en begeleider om bij het juiste systeem tijdig aanwezig te zijn. Met dit centrum gaan we niet alleen in klantvriendelijkheid winnen, maar ook gaan we hiermee in kennis en expertise flink vooruit. MRI is een zeer complexe vorm van beeldvorming en het kost gewoon relatief veel tijd om medewerkers dit eigen te maken, hun daarin te laten groeien en zich te specialiseren. Door nu deze systemen fysiek bij elkaar te plaatsen, bundelen we kennis en ervaring van medewerkers en mogen we daarnaast een verdere slag in efficiëntie van deze vorm van diagnostische zorg gaan verwachten. Anderzijds komt het centrum er ook voor een deel om de niet-electieve zorg te gaan verzorgen. Daarmee bedoelen we dat patiënten gewoon kunnen binnenlopen zonder afspraak, bijvoorbeeld voor een röntgenonderzoek verwezen door de huisarts, en ze hoeven niet diagonaal door het ziekenhuis op zoek naar de afdeling radiologie voor hun onderzoek. Een volgend item voor dit centrum is de koppeling van de spoed eisende eerste hulp die direct aangrenzend en zelfs enigszins geïntegreerd komt te liggen bij de Beeldvorming. Op deze manier worden de mogelijkheden voor de spoedeisende-eerste-hulp-patiënt verder vergroot, aangezien zowat alle beeldvormende modaliteiten in de directe nabijheid liggen. Een bijkomend voordeel is zo dat relatief dure beeldvormende systemen voor meerdere categorieën van patiënten, die 
logistiek te onderscheiden zijn worden ingezet. Dit zal tot een vollediger gebruik van medische apparatuur gaan leiden.

Terug naar de klinische fysica.

\section{Werkterreinen}

In het verleden zijn binnen de Klinische Fysica verschillende specialisaties ingevoerd. Wij noemen dat de zogenaamde werkterreinen. Het zijn er 5 en sommige zijn enigszins overlappend.

Radiologisch klinisch fysici zijn gespecialiseerd in het ondersteunen van apparatuur en methodieken ten behoeve van beeldvormend onderzoek. Hieronder vallen kwaliteitscontroles van röntgenapparatuur, analyse en kwantificatie van radiologische beelden en vooral de introductie van nieuwe technieken. Het meest in het oog springend is dat zij betrokken, of soms zelfs initiator, zijn van nieuwe technologieën ten behoeve van wetenschappelijk beeldvormend onderzoek.

Klinisch fysici nucleaire geneeskunde zijn werkzaam op het gebied van diagnostiek en therapie waarbij gebruik wordt gemaakt van radioactieve stoffen die worden ingebracht. Onder hun werkzaamheden vallen kwaliteitsmetingen aan gamma en PET camera's, dat is het beeldvormingsstuk, en de dosimetrie van patiënten waarin de stralingsbelasting voor de patiënt in detail in kaart wordt gebracht. De vakgebieden Radiologie en Nucleaire Geneeskunde zijn zo zeer verwant/vergelijkend geworden dat ze in de nabije toekomst gaan samensmelten. Klinisch fysici radiotherapie werken nauw samen met oncologen, i.h.b. radiotherapeuten, voor de bestraling van patiënten. De planning van een stralingsbehandeling, zoals voorgesteld door een radiotherapeut, wordt door de klinisch fysicus doorgerekend en gecontroleerd. In recente jaren vindt hier meer en meer beeldvorming plaats zodat de bestraling op basis van beeldmateriaal aangepast gaat worden om zoveel mogelijk het echte tumorweefsel te bestralen en het nabije gezonde weefsel te sparen.

Audiologen zijn werkzaam in audiologische zorgcentra. Zij stellen diagnoses vast en meten auditieve hulpmiddelen aan bij gehoorproblemen. Naast audiologen is de laatste jaren ook een aantal videologen werkzaam, die visuele hulpmiddelen bij patiënten met gezichtsproblemen verzorgen.

De overige klinisch fysici vallen onder het aandachtsgebied algemene klinische fysica. Deze zijn vaak werkzaam in algemene ziekenhuizen, werken meestal op de eerder genoemde terreinen radiologie en nucleaire geneeskunde, maar houden zich daarnaast bezig met bijvoorbeeld laserveiligheid, complexe operatiekamers en intensive care apparatuur en andere medische technieken. Ook de klinische informatica, automatisering, het ons voorzien in digitale informatie, behoort vaak tot hun aandachtsgebied. Daar is nu een nieuwe opleiding voor in opkomst, die van Klinisch Informaticus.

Daarmee zijn Klinisch Fysici niet de enige technologisch geschoolde medewerkers of specialisten. Zo zijn er ook nog medische ingenieurs en biomedical engineers, maar het zijn de enige met een postuniversitaire 4 jarige opleiding die volledig in een 
ziekenhuisomgeving, dus niet in collegebanken, wordt verzorgd om zo een zelfstandige zorgprofessional te worden die kunnen sparren met andere zorgprofessionals.

\section{Opleidingsschets}

De opleiding tot Klinisch Fysicus is tegenwoordig, anders dan vroeger, aan strikte eisen gebonden en gaat dit via een toekenningsmechanisme met kwaliteitscriteria dat is voorgelegd aan de overheid. Het aantal opleidingsplaatsen is gerestringeerd. De vierjarige opleiding tot klinisch fysicus is postacademisch, met als vooropleiding een universitaire fysica of gelijkwaardige opleiding. Qua inhoud en structuur bestaat de opleiding uit een basisdeel dat voor ieder klinisch fysicus vaste onderdelen bevat en een werkterrein specialistisch deel. Hier achter ziet u een schets en de deelonderwerpen.

In het opleidingsland is er veel verandert de laatste jaren en dat lijkt te blijven. De inhoudelijke aspecten van de opleiding zijn daarentegen nauwelijks verandert. Daar waar het voorheen meer op louter inhoudelijke materie gericht was, en hoogwaardige kennis voorop stond, lijken competenties en met name bekwaamheden minstens net zo belangrijk te worden. Klinisch Fysici in opleiding worden niet alleen getraind kennis en vaardigheden maar ook op bekwaamheden zoals men interactie heeft binnen de gehele ziekenhuis omgeving. Ook heeft de beroepsvereniging zich recentelijk aangesloten bij de nieuwe geleding van de Orde van Medisch Specialisten. Daarmee verstevigd men de professionele positie, wordt men een gelijkwaardige gesprekspartner voor overheidsorganen en besturen van zorginstellingen. Ook de opleiding zal meer en meer gespiegeld gaan worden aan die van de medisch specialisten. Daarmee krijgen we ook te maken met de economische teneur in het land, zoals de reductie in financiële middelen om zorgspecialisten op te leiden. Voor de inzet van medische technologie is dit mijns inziens een slechte koers, aangezien de inbreng van de Klinisch Fysicus juist gericht is op het zinvol besteden van zinnige medische technologie. In ons ziekenhuis heeft dat vorm via de commissie medische technologie.

Er zijn momenteel zo'n 22 klinisch fysici in opleiding die jaarlijks instromen in Nederland. Dat aantal zal waarschijnlijk zeer binnenkort reduceren tot zo'n 16 . Het een en ander maakt het dat klinisch fysici in opleiding gering in aantal zijn, zeker voor sommige zorginstituten. Enerzijds is dat vergelijkbaar met de normale klinische praktijk, want meestal opereert men daar als solist op het betreffende kennisterrein. Voor een opleidingssituatie is dat echter niet ideaal en eigenlijk onwenselijk. Idealiter wil je immers in de opleidingsperiode zoveel mogelijk ervaringen opdoen, en dat doe je door het in een groep te delen. Zoiets kan alleen goed werken, wanneer we gaan clusteren. En dat is ook wat er nu door de beroepsvereniging is voorgesteld. Komende tijd zal binnen onze beroepsgroep verkend worden hoe het een en ander gestalte kan gaan krijgen. Voor de regio Zuid-Oost Nederland is er de wil om hier gezamenlijk iets van te maken. 
Terug naar de Medische Beeldvorming, de Radiologie. Welke rol is er in de beeldvorming?

\section{Modaliteiten}

Om $u$ dat te schetsen ziet $u$ hier eerst in een notendop de geschiedenis van de medische beeldvorming.

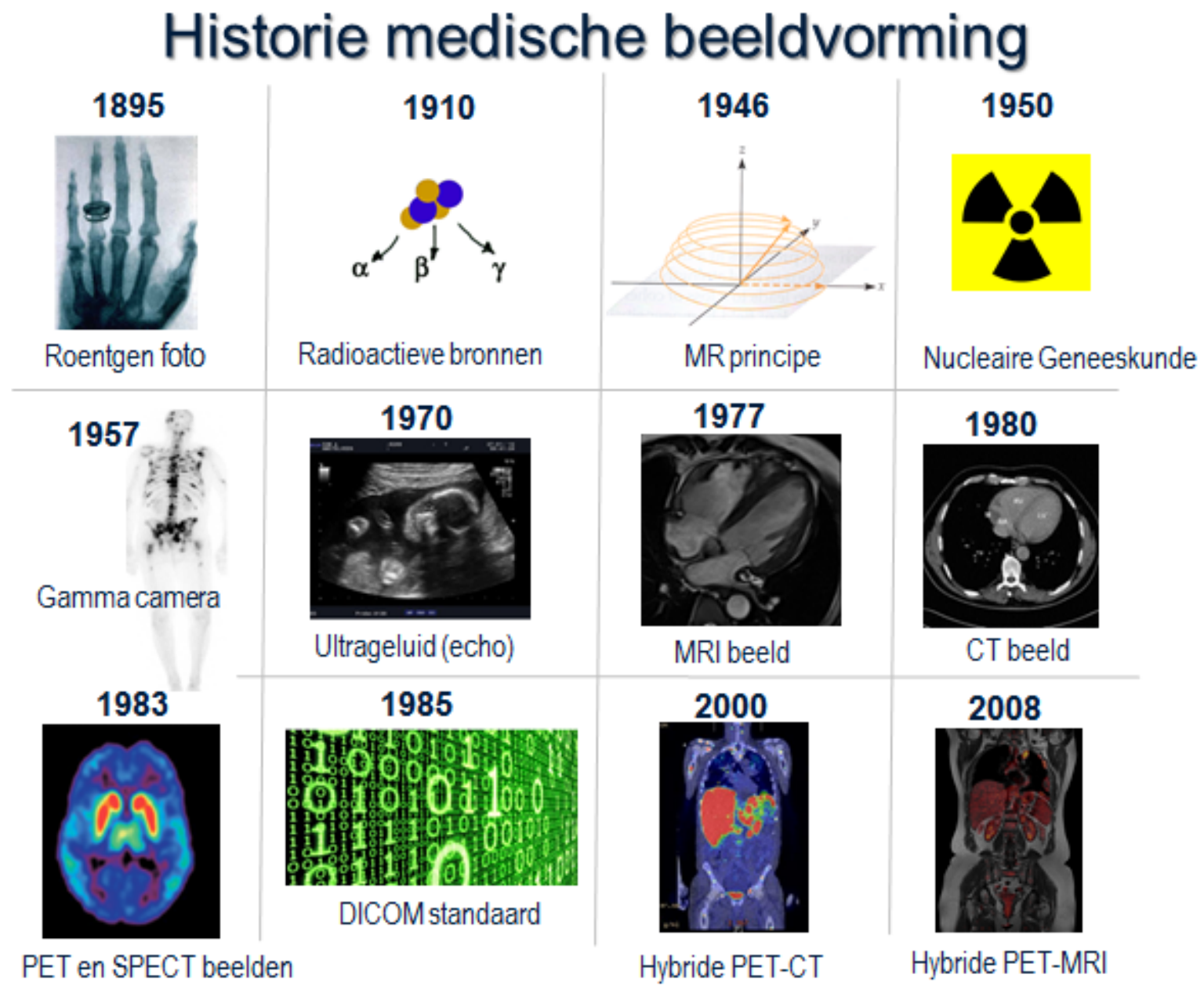

De oudste en veruit meest gebruikte technieken zijn de röntgensystemen, vaak gebruikt als eerste diagnostisch instrument en alom bekend voor het opsporen van bijv. bot-, borst- en longafwijkingen, waarbij de doorlaatbaarheid van röntgenstralen in zogenaamde projectiebeelden wordt weergegeven. Ook is er de echografie, hetgeen werkt met ultrageluid, dat via een sonde/transponder wordt uitgezonden en de terugkaatst, waarna de reflectietijd wordt omgezet in beeldinformatie. Vervolgens is er de CT die een rondom-meting met röntgenstralen verricht, en waarmee aldus driedimensionale beelden kunnen worden gemaakt en dus echt waarheidsgetrouw in de diepte van het lichaam kan worden gekeken. Voorts zijn er technieken waarmee organische stoffen, gekoppeld aan radionucliden, de zogenaamde radiofarmaca, kunnen worden afgebeeld. Hier heb je een aantal varianten van zoals de gammacamera, SPECT, en PET, die verschillen ten aanzien van diepte informatie en 
welke radionucliden worden gebruikt. Als laatste is daar de MRI, de zogenaamde magnetische resonantie imaging, een techniek waarmee de magnetische eigenschappen van voornamelijk het weke weefsel heel goed kan worden afgebeeld. Het bijzondere aan al deze technieken is dat het berust op complexe natuurkundige principes, zoals het absorberen en doorlaten van röntgenstraling, of de weerkaatsing van geluidsgolven of de beïnvloeding van magnetiseerbare deeltjes in ons lichaam. Veel fysici hebben meegewerkt aan of lagen zelfs aan de basis bij de uitvinding van de technieken. Als u kijkt naar de jaartallen van de totstandkoming, dan lijkt het alsof er de laatste jaren geen gloednieuwe technieken meer worden geïntroduceerd, behoudens dan het samenvoegen van lossen modaliteiten zoals de PET-CT en recentelijk de PET-MRI. Daar speelt echter nog iets anders. Al deze technieken zijn aan voortdurende verandering en verbetering onderhevig, zij het doordat het systeem an sich verder wordt ontwikkeld of dat er nieuwe inzichten komen voor de juiste toepassingen. Of er een gloednieuwe techniek te verwachten valt dat is altijd afwachten en berust op de eerste plaats op vindingrijkheid. Echter dat niet alleen, de kosten die gemoeid gaan met het ontwikkelen van gloednieuwe systemen worden gigantisch, en zijn vergelijkbaar met het bouwen van de kathedralen in de middeleeuwen. Een taak van klinisch fysici, vooral in de academische ziekenhuizen is heden ten dage vooral het exploreren van nieuwe toepassingsmogelijkheden voor medische zorg, in het bijzonder de diagnostiek.

\section{Radiologische diagnostiek}

Voor die diagnostiek zijn het de artsen, in het bijzonder radiologen, die kijken naar beelden, en hoofdzakelijk op zoek zijn naar het herkennen van vormen, structuren en patronen. Zij als artsen hebben gedegen kennis van ziekte processen en welke afwijkingen in het lichaam daarbij horen en weten die te herkennen. Het gaat daarbij veelal om het herkennen van structurele afwijkingen die passen bij een klinisch beeld, dus de beschrijving van die klachten. En alhoewel voor het maken van dit soort beelden geavanceerde apparatuur nodig is, dat is hoogwaardig ingenieurs werk puur sang, komt aan het beoordelen van dit soort beelden geen tot zeer weinig gecijfer te pas. Voor de directe patiëntenzorg gaat het dus vooral om het woordelijk beschrijven van de afwijkingen, vergezeld van beelden die dit ondersteunen.

\section{Kwantificatie}

Echter als je verbeteringen of geheel nieuwe mogelijkheden wil exploreren, zul je vaak gebruik moeten maken van kwantitatieve informatie, en bij voorkeur getallen die je kunt ontleden uit beelden die je kunt uitdrukken in fysische eenheden zoals afmetingen in centimeters, en stroomsnelheden als $\mathrm{mL} / \mathrm{min}$, etc. Alleen dat is de controleerbare manier om vooruitgang in Beeldvorming te objectiveren.

Abstract gedacht, zijn er minstens 7 argumenten te verzinnen waarom wetenschap van de Beeldvorming gebaat is bij het gebruik van cijfers of, nog beter, kwantitatieve maten. Voorbeelden volgen achteraf.

Allereerst is er (i) de objectivatie. Kijken naar beeldintensiteiten kan ook nooit uniek zijn, het herinstellen van de schermcontrasten geeft een verschillende indruk van wat 
er wordt bestudeerd. Voor (ii) het verbeteren van beeldkwaliteit zijn er referentiewaardes nodig om te vergelijken en bij voorkeur zouden intensiteiten uitgedrukt worden in fysisch of fysiologische maten zodat ze zoveel als mogelijk apparaat onafhankelijk zijn.

Wanneer relevante effecten op beelden gering/klein zijn speelt ruis vaak een min of meer prominente rol, dan is er vaak twijfel of effecten zichtbaar zijn. Kwantificatie kan daarbij (iii) de gevoeligheid verhogen. In het bijzonder voor medisch onderzoek is het van belang dat het valide is wat je meet, dat check je door metingen onder dezelfde condities te herhalen. Kwaliteit van metingen wordt dan bepaald door (iv) een reproduceerbaarheidswaarde te geven, die bijvoorbeeld weergeeft hoeveel procent twee metingen van elkaar verschillen.

Dan kom ik op een van mijn beweringen. Klinisch wetenschappelijk onderzoek waarbij gemeten wordt dient niet na maar juist voor publicatie duidelijk te maken hoe reproduceerbaar het is, met getal en maat. Het komt nog maar al te vaak voor dat relatief nieuwe vormen van onderzoek worden getracht na te doen, maar niet reproduceerbaar blijken. Het toevoegen van reproduceerbaarheid zal het medisch onderzoek in een beter daglicht brengen.

Een volgende is het feit dat een getal vaak (v) een simplificatie is van de werkelijkheid, en juist datgene eruit kan halen wat voor diagnose of behandeling relevant is. Bij geavanceerdere vormen van medische Beeldvorming maken we gebruik van films, dynamische beelden van bewegende of veranderende lichaamssignalen zoals het pompende hart of het werkende brein.

Een item waar recentelijk veel over te doen is (vi) het begrip biomarker. In deze context betekent dit vaak een effect zichtbaar op medische beelden waaraan een getal wordt toegekend, en waaruit blijkt dat dit getal afwijkt bij een bepaalde aandoening of ziekte ten opzichte van gezonde personen die als referentie dienen. Zo meteen laat ik $u$ daar een reeks van voorbeelden zien. Vergeet daarbij a.u.b. niet dat zulke biomarkers niet bepalen $u$ of gezond of ziek bent. Daar is wezenlijk meer voor nodig, het dient meer als additioneel gegeven in een reeks van bevindingen die een diagnose kunnen versterken.

Een laatste is dat door gebruik te maken van kwantificatie er ook (vii) een foutenanalyse gemaakt kan worden. Zo kan de invloed van allerlei factoren met getallen in kaart worden gebracht om in te schatten wat, bijv. welke instellingen zinvol zijn om voor verbetering aan te pakken.

Enkele van deze aspecten zitten verweven in het wetenschappelijke onderzoek, dat nu volgt.

\section{Wetenschappelijk onderzoek - beeldvorming en epilepsie}

Ik begin met het epilepsie imaging onderzoek. Voor dit klinische onderzoek heb ik zeer veel jaren samengewerkt met prof. Bert Aldenkamp, o.m. van het Kempenhaegse Epilepsie Centrum.

De inhoud van het onderzoek volgt zo meteen. Het unieke van onze samenwerking was de introductie van het zogenaamde twin-model. In dit model wordt een medicus, vaak een arts in opleiding, gekoppeld aan een technologisch geschoolde ingenieur. 
Met deze koppeling van disciplines, met totaal verschillende culturen, hebben we de juiste synergie weten te realiseren om lang liggende klinische vragen met moderne technologie te beantwoorden. En niet andersom, bij dit onderzoek stond de medische vraagstelling stond voorop en de gehanteerde methode was ten dienste hiervan.

\section{Promovendus begeleidingsmodel}

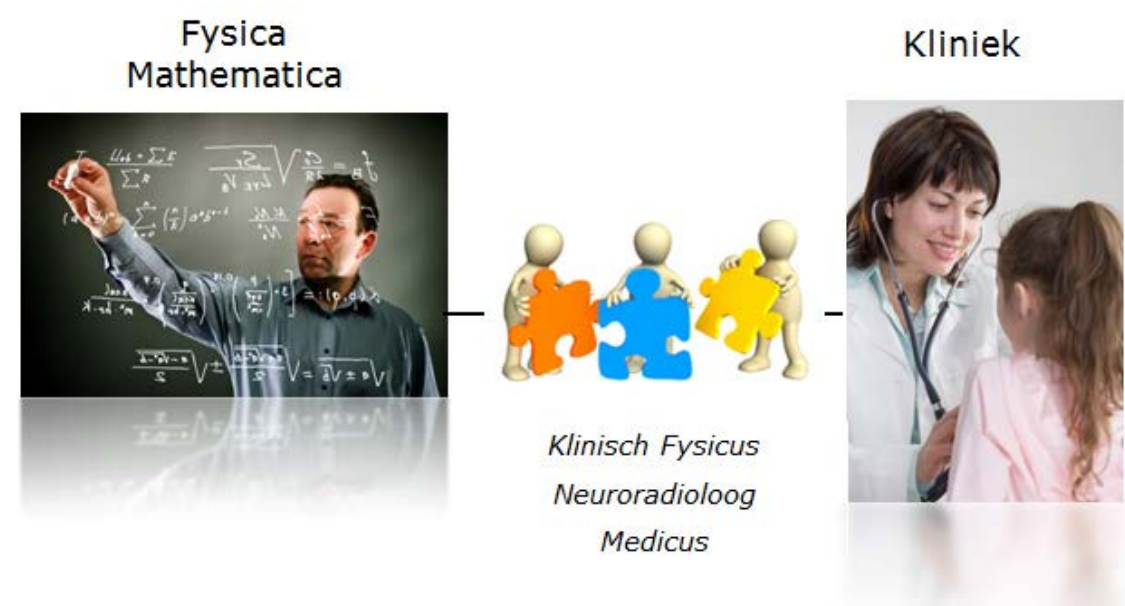

Epilepsie is een aandoening die wordt gekenmerkt door epileptische aanvallen, hetgeen het gevolg is van een soort van spontane kortsluitingen in de hersenen. Tijdens zo'n aanval kan de controle over het lichaam worden verloren of het bewustzijn wegvallen. Het is de meest voorkomende ernstige neurologische aandoening van ons menselijk brein. In het bijzonder hebben we naar de gevolgen van deze aanvallen op het brein gekeken, de zogenaamde chronische epilepsie. Wat daarbij blijkt is dat er ten aanzien van het denkvermogen, zeg de cognitie, aanzienlijke blijvende schade kan optreden. Hier links ziet u een activatiefoto, gemaakt met functionele MRI, van een groep patiënten met een chronische vorm van epilepsie. Het komt uit de promotieonderzoeken van Mariëlle Vlooswijk en Maarten Vaessen, een mooi voorbeeld van het twin-model. Als je hun een taak geeft die een beroep doet op het denkvermogen, bijvoorbeeld zoveel mogelijk woorden noemen die met een bepaalde letter beginnen, een taaltaak, dan presteren ze daar duidelijk minder en vooral trager op dan gezonde controle personen die als referentie dienen. En ondanks dat verminderde vermogen, zie je in de hersenen vergelijkbare activatie patronen over verschillende delen van het brein. In detail lijken er wel verschillen, maar grosso modo zijn de activatiegebieden vergelijkbaar voor de beide groepen. Dit soort metingen zijn overigens maar matig reproduceerbaar, en zijn vaak het gemiddelde van vele patiënten.

Waar het hier omgaat is dat er nieuwe technieken nodig waren om dit raadsel toch te ontcijferen, d.w.z. hoe het hersenweefsel het cognitieve falen kan weergeven ondanks dat het activatiepatroon toch zeer vergelijkbaar is. Dit heeft alles te maken met een nieuwe ontdekking van de afgelopen jaren die te vatten is in de term: netwerken. Voor een complexe functie als taal, want dat is het verzinnen van 
woorden, is het niet zo dat een enkel geïsoleerd gebiedje in het brein verantwoordelijk is. Functies van het brein worden voortgebracht door netwerken, een gedistribueerde set van gebieden die in harmonie samenwerken. Betekent ook dat deze gebieden enige gelijkenis in de tijd zullen tonen in het dynamisch signaal dat ze afgeven, hetgeen te meten is met MRI.

Als je het gaat inventariseren blijken de gelijkeniscijfers, de zogenaamde correlatiecoëfficiënten, systematisch lager uit te vallen voor de patiënten met epilepsie dan voor gezonde controles. Dit is louter een constatering, hetgeen niet meteen duidelijk maakt of het gaat bijdragen aan de zorg voor deze patiënten.

\section{Uitrekenen van netwerken}

Voor het bepalen van netwerken in ons brein maken we gebruik van grote computer cluster systemen, die bij ons op de afdeling worden opgezet door onze applicatieontwikkelaars Marc Geerlings en Jos Slenter. Dit zijn samengestelde computersystemen die parallel, tot zo'n 64 rekeneenheden, enorme grote data sets van beelden, $10 \mathrm{~K}-100 \mathrm{~K}$ beelden per patiënt, kunnen doorrekenen volgens pipeline schema's zoals die hier zijn afgebeeld.

\section{Computer clusters}

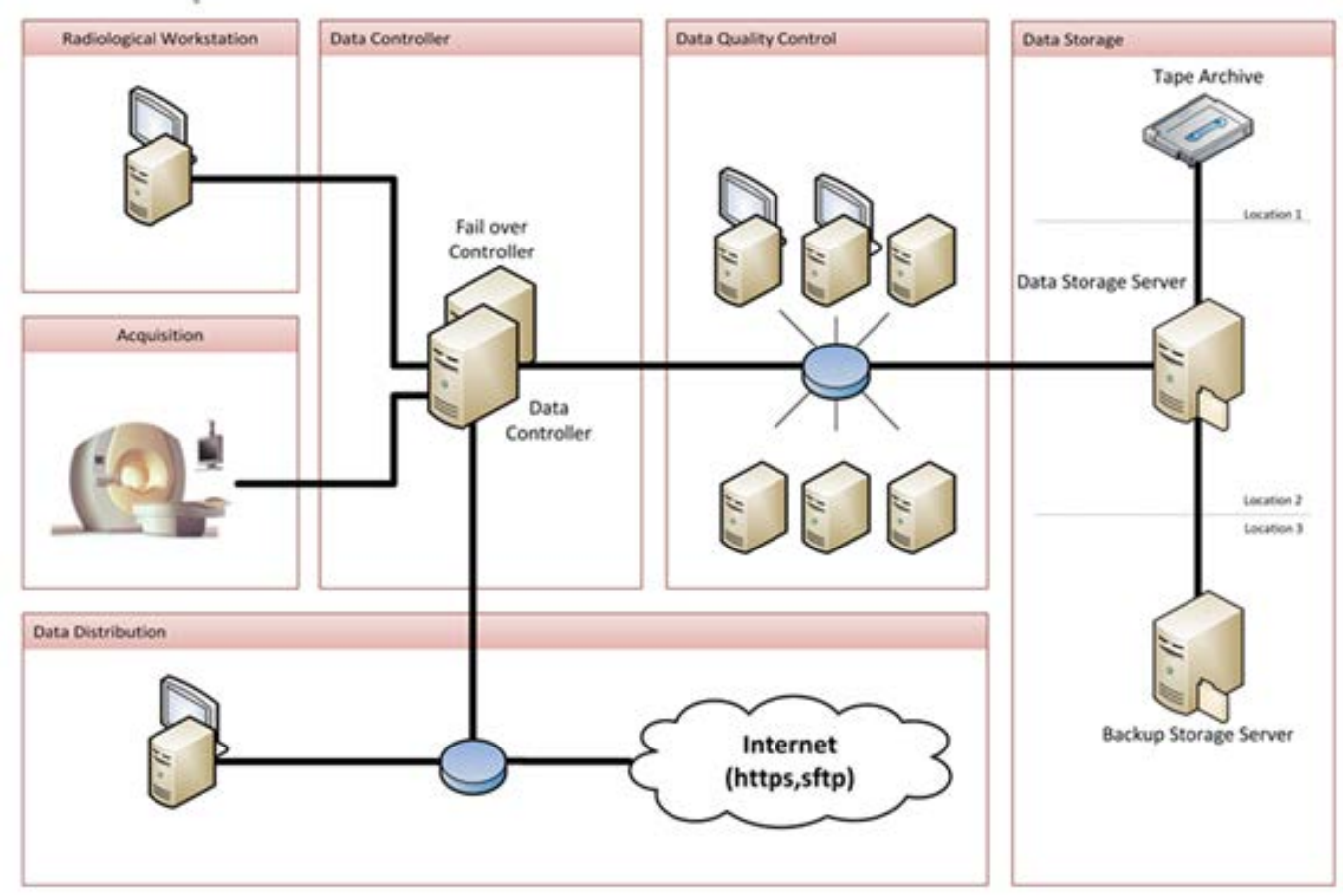

Waar het in essentie om gaat is dat de hersenen op de foto's worden ontleedt in diverse onderdelen, bijvoorbeeld witte en grijze stof, maar ook gebieden die vooraf enigszins bekend zijn in de zin bij wat voor soorten van functies ze een rol spelen. En tussen die gebieden worden verbindingen uitgerekend. Enerzijds kan dat door een gelijkenisgetal dat aangeeft hoe synchroon het tijdactivatiepatroon tussen twee gebieden verloopt. Anderzijds kan dat ook door de witte stof banen, de tracts, dat zijn fysieke verbindingen zeg maar stroomkabelbundels, tussen de verschillende 
hersengebieden te tellen. Zo zijn er allerlei manieren om tussen een groot aantal hersengebieden de verbindingen te bepalen. Als je het brein in een lappen deken van zo'n 90 gebieden opdeelt, dan kom je al gauw uit op zo'n ruim 4000 verbindingen, dus 4000 getallen, die je kunt weergeven in een connectiematrix. $U$ kunt zich voorstellen dat men met al deze cijfers al gauw het overzicht verliest. Een manier om met zo'n grote hoeveelheid aan connectiegetallen om te gaan, is gebruik te maken van grafentheorie. Met grafentheorie wordt een poging gegaan deze getallen massa te comprimeren in een relatief klein setje van getallen, wederom de biomarkers, die enig inzicht geven in de structuur van het netwerk van ons brein. Zo kan men gebruik maken van de padlengte, dat aangeeft in hoeveel stappen men van de ene gebied naar het andere gebied komt gemiddeld over alle gebiedsparen. Daarna is er de clustering, die aangeeft of twee buurgebieden op zijn beurt ook weer buurgebieden van elkaar zijn, zeg maar het aantal driehoekjes dat je kunt tellen in zo'n graaf. Zo zijn er nog heel veel meer maten, die aangeven hoe de infrastructuur van onze hersenen is georganiseerd opdat langs een efficiënte wijze informatie verwerkt kan worden.

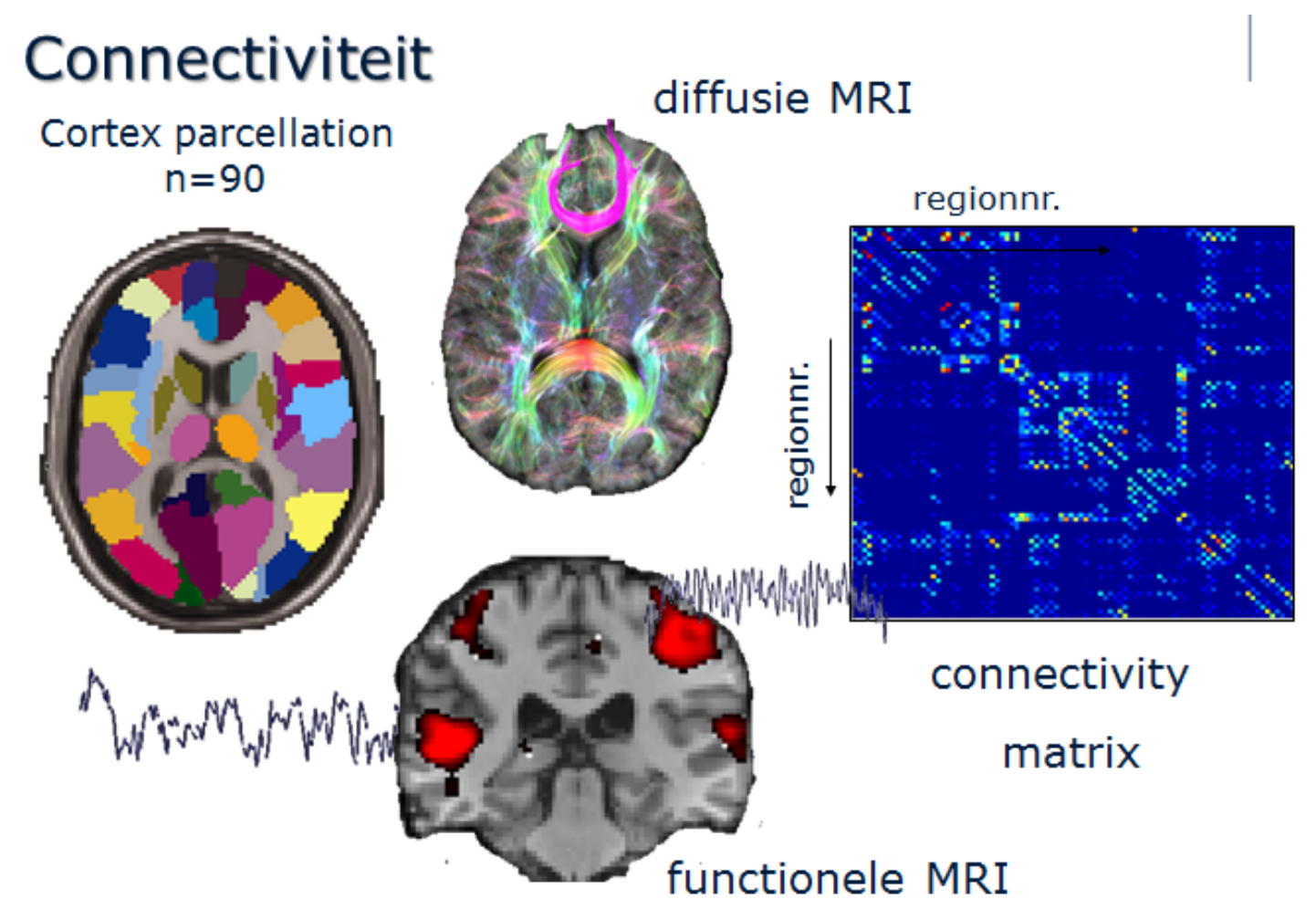

Deze graafmaten bleken ook voor het eerst iets te zeggen over de intelligentie van ons brein. Zo ziet $u$ hier een vroege publicatie van Maarten van den Heuvel die aangeeft dat intelligentie enigszins correleert met bepaalde netwerk eigenschappen van ons brein, uitgedrukt in padlengte en clustering van gebieden. Maar ook voor hersenaandoeningen zoals chronische epilepsie geven zij waarden die een afbraak van de netwerken weergeven. Daarbij kan ik u vertellen, dat deze maten wel zeer reproduceerbaar zijn. 
De effecten die ik u daarstraks liet zien treden niet alleen op bij volwassenen, maar ook bij kinderen. Bijvoorbeeld kinderen met rolandische epilepsie, een zeer veel voorkomende vorm van epilepsie die zich kenmerkt door nachtelijke aanvallen, waarna kinderen op school of in sociale omgangsvormen achterblijven. Met name de taal is daar een in het oog springende eigenschap die achterblijft. Daarbij moet $u$ weten dat bij rolandische epilepsie de kortsluitingen ontstaan in de motorschors, het gebied dat verantwoordelijk is voor het aansturen van o.a. onze ledematen, en dat lijkt op het eerste gezicht niets te maken te hebben met taalnetwerken zoals wij die ons brein hebben. Echter wederom met de netwerktheorie kun je laten zien dat functionele verbindingen zoals hier aangegeven tussen een centrum van een taalnetwerk (voor de kenners broca's gebied, oranje) en de motor schors (groen) afwijkend zijn. Het zijn foto's uit de promotieonderzoeken van Geke Overvliet en René Besseling, wederom een voorbeeld van het twin-model. Dit blijkt dan ook nog verband te houden met de mate waarop de taal onderpresteert in deze kinderen. Het voegt dus begrip/inzicht toe over hoe ons brein werkt, en in het bijzonder hoe het afwijkt voor bepaalde hersenaandoeningen. Wat zou je ermee kunnen? Je kunt kijken naar een selectie van medicatie die wordt gebruikt. Zo weten we dat bepaalde medicatie er om bekend staat dat deze bijwerkingen, met name cognitieve bijwerkingen, geven. Het lopende onderzoek van Tamar van Veenendaal poogt aan te tonen dat anti-epileptica de hersenen qua netwerk structuur aantasten en mogelijk zullen we daartoe van medicatie gaan veranderen in de nabije toekomst. Er komen dus diagnostische tools beschikbaar die in zeker detail de reacties van het hersenweefsel kunnen monitoren, waarmee dus niet eerder gebruikte vormen therapie nauwlettend in de gaten kan worden gehouden.

Een ultiem doel zou zijn om die mensen te identificeren die een enkele aanval hebben gehad, zich melden bij de poli Neurologie, en te voorspellen of er een volgende aanval wel of niet gaat komen. Het cijfermatige doel daarbij is die kenmerken of waarschijnlijk onregelmatigheden, zogenaamde biomarkers, te ontdekken die voorspellen of de patiënt het bij die ene aanval zal laten of daadwerkelijk een epilepsie syndroom aan het ontwikkelen is en verdere aanvallen zal tonen in de toekomst. De ultrahoog veld MRI systemen zoals die nu beschikbaar zijn bij de faculteit Psychologie en Neuroscience zullen hierbij, zo is de verwachting, zeer behulpbaar zijn.

\section{Wetenschappelijk onderzoek - beeldvorming en microvasculatuur}

Dan het andere onderwerp dat hier weinig mee te maken lijkt te hebben. Dat is slechts ogenschijnlijk zo.

Kleine bloedvaten. Er is de afgelopen jaren zeer veel medisch wetenschappelijk onderzoek verricht naar de aandoeningen van onze grote bloedvaten, voor het transport van bloed naar en de doorbloeding van allerlei organen, en anderzijds op de functie van de organen. Echter door de organen heen bevinden zich ontelbaar veel kleinere zeg perforerende bloedvaten die het bloed voorstuwen en het zuurstof en voedingsstoffen bij de cellen brengen en vervolgens afvalproducten afvoeren. Maar ook die vaten kunnen aandoeningen hebben, maar zijn tot op heden met 
beeldvorming niet of nauwelijks in beeld te brengen.

Van de afwijkingen in kleine bloedvaten is wellicht de bekendste de vaatwoekering in groeiende tumoren, de zogenaamde angiogenese. Voor de tumorgroei worden die vaten worden vaak snel gevormd en worden daarom niet geheel volwassen. Zo hebben deze allerlei gaten/openingen in de wand waardoor een magnetische merkstof, een contrastmiddel, gemakkelijk de bloedbaan kan verlaten. Hier ziet u bijvoorbeeld van de lekkage door hyperpermeabele vaten in het darmkanaal, het zijn de rectumtumoren uit het proefschrift van Quido de Lussanet. De hyperpermeabele bloedvaatjes zijn hier zichtbaar gemaakt door het lekken van contrastmiddel uit de bloedbaan naar het tumorweefsel. Zulke sterk lekkende bloedvaten is iets wat je wilt tegengaan, aangezien er ook nog op deze manier tumorcellen via de bloedbaan kunnen gaan uitzaaien. Ook het omgekeerde komt voor. Hier ziet u een voorbeeld waar je graag de groei van kleine vaten juist zou willen stimuleren. Dat speelt bijvoorbeeld voor onze hersenen. $U$ ziet een infarct, beter gezegd een hematoom, met daaromheen aankleuring van het contrastmiddel. Het stellen wederom de vaatjes voor die hyperpermeabel zijn en in dit geval een poging doen om de inperking van de doorbloeding door het infarct te compenseren.

Voor de hersenen van ons ligt het, als zo vaak, een stuk gecompliceerder. Het bijzondere voor ons brein is dat het contact tussen bloed, bloedvat en hersencellen indirect, strikt genomen gescheiden is. Er zit een barrière tussen. Die barrière is zodanig dat zuurstof en hormonen redelijk ongehinderd kunnen uitwisselen maar dat andere deeltjes/moleculen, zelfs water, en in het bijzondere grotere deeltjes niet zomaar deze grens kunnen passeren. Op die manier regelt het brein zijn evenwicht, de homeostase.

$\mathrm{Nu}$ dit regelmechanisme is redelijk robuust en werkt beschermend. Echter ouderdom en vaataandoeningen, met name de welbekende atherosclerose, beïnvloeden de conditie van de vaatwand in negatieve zin.

Tot op heden wordt kennis van de integriteit van de bloed-brein-barière vooral verkregen uit gegevens van overleden patiënten, waaruit het hersenweefsel kan worden gewonnen. In de levende mens wordt daarvoor het albumine gehalte bepaald in de ruggenmergvloeistof, dat gaat echter via een ruggenprik, hetgeen veilig maar toch niet ongecompliceerd is. Echter albumine is een vrij groot molecuul met een gewicht van zo'n 50 kiloDalton, en die barrière moet al in een relatief ver gevorderd stadium van achteruitgang zijn mocht albumine meetbaar zijn. Idealiter zou dit je weer met een merkstof willen bepalen, die bij voorkeur via de bloedbaan het brein bereikt en daar de barrière passeert.

In de levende patiënt was dit tot voor kort niet of nauwelijks mogelijk, behalve dan in hersentumoren van een hoge graad. Gangbaar daarvoor was om met een contrastmiddel de bloedbaan aan te kleuren, en dat dit in het brein uitwast en daar het weefsel aankleurt. Dat kennen we voor tumoren zoals hier geschetst of infarcten waarbij de er nieuwe bloedvaten gaan vormen. Het normaal ogende weefsel kleurt niet aan. Echter ook voor gewone ouderdom, diabetes, de ziekte van Alzheimer, of vasculaire vormen van dementie en hypertensie is het zeer waarschijnlijk zo niet al bewezen, dat de bloed-brein-barrière een onderlinge reden is dat het functioneren 
van onze hersenen achteruit gaat en dus ook het instorten van onze netwerken plaatsvindt. Om het effect echter zichtbaar te maken in ons menselijk brein zijn nieuwe meer gevoelige technieken nodig dan tot op heden gebruikt. Nu recentelijk lijkt dat gelukt voor een eerste groep alzheimer patiënten. Hier de studie van Harm van de Haar uitgevoerd in samenwerking met prof. Verhey en Saartje Burgmans van het Alzheimer Centrum Limburg. Wat $u$ ziet is de uiterst geringe aankleuring van het contrastmiddel door een kaduke bloed-brein-barrière van een alzheimer patiënt. Het gaat hier om een uiterst klein effect, althans voor zover het meetbaar is. Echter de gevolgen kunnen enorm zijn, daar waar een bloed-brein-barrière lekt, kunnen toxische stoffen zo de neuronen bereiken en worden afvalstoffen die niet voldoende afgevoerd worden mogelijk opeens toxisch. En het feit dat het op de grens van het meetbare is, zo'n 10-20x kleiner dan bij hersentumoren, maakt het dat hier ingenieurs voor nodig zijn, die het signaal kunnen verbeteren en weten om te gaan met ruizige beelden en reproduceerbaarheid van datgene dat gemeten wordt. Dit gaan we voortzetten in patiënten met de ziekte van Alzheimer en vooral in die patiënten met verwachte voorstadia daaraan, hetgeen het promotieonderzoek is van Whitney Freeze. Daarmee willen we gaan vaststellen welke rol vasculaire factoren hebben en dus bepalen of ze van invloed zijn op ons verouderende brein.

Ook gaan we dit toepassen voor patiënten met subtielere vormen van vasculaire aandoeningen zoals lacunaire infarcten i.s.m. met prof. Van Oostenbrugge. $\mathrm{Nu}$ het lekken kunt u ook op een schaal voorstellen van groot naar klein. Groot is bijvoorbeeld een bloeding, waarbij rode bloedcellen de bloedbaan verlaten, de volgende stap zijn dan de grote moleculen zoals bijvoorbeeld albumine, en daarna kleinere deeltjes zoals een magnetisch contrastmiddel. Nu het allerkleinste is waarschijnlijk water.

\section{Diffusie MRI}

Ook daar zijn we voor aan de slag. Water kent een random, diffuse beweging in het brein, de zogenaamde brownse beweging. Dit wordt al jaren gebruikt om bijvoorbeeld het watertransport en permeabiliteit van de nerven van de bladeren van planten te meten. Met diffusie gewogen MRI kunnen we heel nauwkeurig meten wat het transport en toegankelijkheid van water is. Dan moet u denken aan random bewegingen van enkele vierkante micrometers in 1 duizendste van een seconde. Dat zal verschillen of het water moleculen zijn die in een bloedvaten bewegen, waar meer ruimte en stroming is of tussen de hersencellen in. Tussen de cellen zullen water moleculen meer hinder ondervinden. Recentelijk zijn we in staat gebleken om dit te scheiden. Het is het onderzoek van Frank van Bussel, waarbij we gaan kijken in patiënten met diabetes. Ook zijn we voor kleine diepe herseninfarcten met een variëteit aan cognitieve klachten aan de slag met weer een twin Eleana Zhang en May Wong. Dus het twin-model breidt zich uit naar vatenonderzoek. 


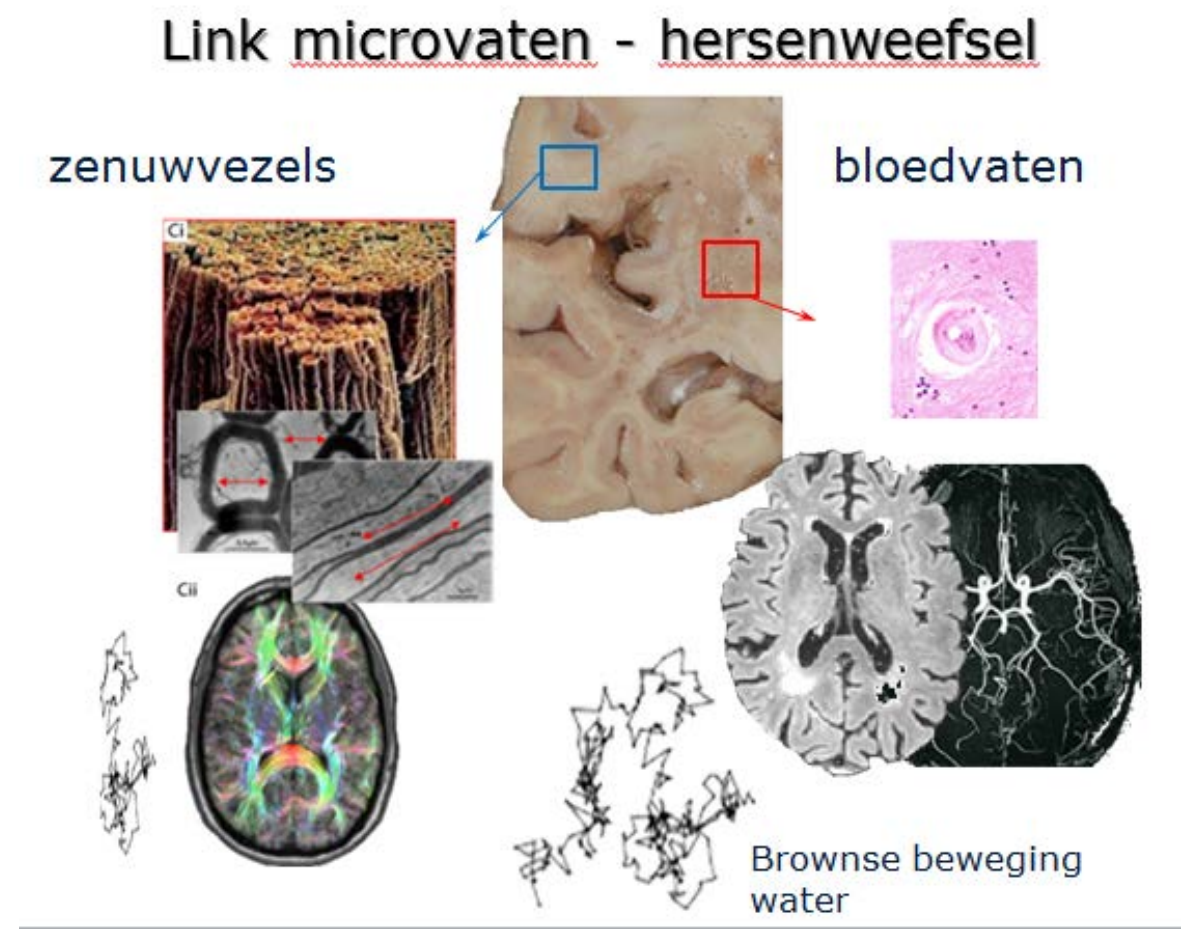

Tot zover het passieve transport van deeltjes door de vaatwand die aldaar de conditie van neuronen negatief beïnvloeden.

Maar er zijn ook meer subtiele vormen van transport die energie kosten en specifieke biochemische transportmechanismen vergen. Veel van deze zijn bekend, maar ook vele zijn onbekend, zeker in de context van aandoeningen van hersenvaten. Zulk actief transport kunnen we ook volgen, door gebruik te maken van radiofarmaceutica. lets waar we in onze groep op hopen is het specifieke transport na te bootsen met de nieuwste vorm van hybride Beeldvorming: de PET-MRI. Daartoe heeft het azM in deze zomer een nieuw simultaan PET-MRI system geïnstalleerd, en we hopen dan ook hiermee nieuw inzichten te krijgen voor de aandoeningen van de bloedvaten.

Het vinden van een oplossing, niet alleen voor behandeling, maar ook voor diagnostiek van een aandoening is een lange weg. In het bijzonder is er een belangrijke rol voor vernieuwende methoden, zeker voor die aandoeningen waar er voorheen geen mogelijkheden leken te zijn. Enkele daarvan heb ik u proberen te illustreren. 


\section{Dankwoord}

Afsluiten ga ik met enkele woorden van dank. Er zijn velen zo niet bijna ontelbaar veel mensen die ik te danken heb voor het werk dat ik de afgelopen jaren heb mogen doen, en ook de weg naar deze leerstoel.

Laat ik beginnen met prof. Van Engelshoven, voormalig afdelingshoofd. Heel hartelijk dank voor de kans die u me destijds gaf om hier te starten en ook de mogelijkheden om me verder te ontwikkelen. Je zei ooit, ik heb je nog nooit iets verboden, dat ben ik niet vergeten.

Ook heel bijzondere dank aan Gerrit Kemerink, die me destijds samen met Paul Hofman, de voorkeur onder de sollicitanten gaf. Gerrit, je bent nu inmiddels al enige tijd met pensioen, maar ik mis de inhoudelijke discussies die we voerden enorm. Ook Paul, alle dank voor de input en samenwerking met name op het epilepsie imaging deel. Ik kon en kan altijd bij je aankloppen. Je aandacht schuift meer en meer richting forensische radiologie, hopelijk blijven we toch dingen samen doen.

Beste prof. Post, jij bent degene geweest die me aanstak voor het kleine vaten onderzoek. Dank voor je open en gastvrije houding. Ik heb immens veel van je geleerd.

Prof. Aldenkamp, wat was er een drive en lol voor het epilepsie onderzoek. We hebben een fase gekend waarbij het ene na het andere idee verzilvert bleek te worden en uit monde in tal van artikelen en promoties. Ik hoop dat nu je een ingenieur bent geworden, we kunnen blijven samenwerken.

Prof. Wildberger, hartelijk dank voor je inspanningen om dit vandaag mogelijk te maken. Het aantal musketiers neemt toe. En ook alle dank voor de steun en stimulans aan de opleiding Klinische Fysica. Datzelfde geldt ook voor prof. Wijn van het Máxima MC en de inspanningen van Cécile Jeukens.

Dan Jaap Jansen, je was een van mijn eerste promovendi, trouwens zeker niet de meest vooruitstrevende. Een switch naar de VS en weer terug heeft je enorm goed gedaan. En inmiddels ben je niet meer weg te denken voor het neuroonderzoek. Hou dat zo.

Evenzo alle promovendi, waarvan ik er al velen heb gezien hier in de zaal. Het is nog steeds een lust om met jullie werk terug te zien en het onderzoek te doen.

Ook ben ik alle dank verschuldigd aan de laboranten, met name de MRI en CT voor alle steun en geduld bij het regelen van scantijd en de zowel de succesvolle als niet succesvolle metingen.

Verder de dames van het secretariaat, Monique, Christianne, Peggy, Elfie en Margriet, die mij altijd bijstaan en geen verzoek te veel is.

Dan naar de persoonlijke kring.

Pap, je hebt me altijd aangemoedigd en gesteund in wat ik in mijn hoofd haalde en hoe ik het ook deed. Ik weet het, ik was een makkelijke leerling, maar toch je steun was onvoorwaardelijk en dat betekent veel voor iemand al realiseer je dat pas met de jaren.

Mam, jij was er altijd voor me en ik hoop dat ik er nu het minder gaat ook voor jou kan zijn, zeker als het nodig is. 
Emma, Sofie en Raf. Voor diegene die twijfelt, Raf is jongste spruit in het midden. De andere 2 uitleggen is wat ingewikkelder. Jullie zijn het grootste geluk wat iemand kan overkomen. Emma en Sofie sinds kort op een nieuwe school en leerlingen in de breingeheimen, hopelijk hebben jullie er wat van opgestoken. Het was een genot om jullie te zien komen en nu te zien opgroeien en zelfs te puberen. Morgen is er weer hockey en staan we weer langs het veld en moedigen jullie aan.

Aan het einde van de rij, Suzan. We kennen elkaar al meer dan 25 jaar. Het moet gezegd zijn: zonder jou was het allemaal niets in vergelijking zoals het nu is.

Gelukkig. Mijn dank aan jouw is onbegrensd, en de liefde is onvoorwaardelijk en moge het voor altijd zijn.

Dank aan u allen voor uw komst en aandacht.

Ik heb gezegd. 